The Wind Doesn't Need a Passport 
The publisher gratefully acknowledges the generous support of the General Endowment Fund of the University of California Press Foundation. 


\title{
The Wind Doesn't
} Need a Passport

STORIES FROM THE U.S.-MEXICO BORDERLANDS

\author{
Tyche Hendricks
}

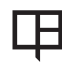

UNIVERSITY OF CALIFORNIA PRESS

BERKELY LOS ANGELES LONDON 
University of California Press, one of the most distinguished university presses in the United States, enriches lives around the world by advancing scholarship in the humanities, social sciences, and natural sciences. Its activities are supported by the UC Press Foundation and by philanthropic contributions from individuals and institutions. For more information, visit www.ucpress.edu.

University of California Press

Berkeley and Los Angeles, California

University of California Press, Ltd.

London, England

(C) 2010 by Tyche Hendricks

Portions of this work originally appeared, in different form, in the San Francisco Chronicle series "On The Border," published in 2005, 2006, and 2007. That material is reprinted by permission from the San Francisco Chronicle. Copyright (C) 2005, 2006, and 2007, The Hearst Corporation. All Rights Reserved.

Library of Congress Cataloging-in-Publication Data

Hendricks, Tyche.

The wind doesn't need a passport : stories from the U.S.-Mexico borderlands / Tyche Hendricks.

p. $\mathrm{cm}$.

"Portions of this work originally appeared, in different form, in the San Francisco Chronicle series "On The Border."

Includes bibliographical references and index.

ISBN 978-0-520-25250-9 (cloth : alk. paper)

I. Mexican-American Border Region-Social conditions. I. Title.

$\mathrm{HN}_{79} \cdot \mathrm{Ar}_{65} \mathrm{H}_{4} 62010$

$303.48^{\prime} 20972 \mathrm{I}-\mathrm{dc2} 2$ 2009046593

Manufactured in the United States of America

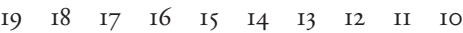

IO $\quad 9 \begin{array}{lllllllll} & 8 & 7 & 6 & 5 & 4 & 3 & 2 & \text { I }\end{array}$

This book is printed on Cascades Enviro IOO, a IOO\% post consumer waste, recycled, de-inked fiber. FSC recycled certified and processed chlorine free. It is acid free, Ecologo certified, and manufactured by BioGas energy. 
For Paul, my partner on the journey 
This page intentionally left blank 